\title{
anatomy and Physiology of Cattail as Related to Different Population Densities ${ }^{1}$
}

\author{
Anatomia e Fisiologia de Taboa em Relação a Diferentes Densidades Populacionais \\ CORREA, F.F. ${ }^{2}$, MADAIL, R.H. ${ }^{3}$, BARBOSA, S. ${ }^{4}$, PEREIRA, M.P. ${ }^{2}$, CASTRO, E.M. ${ }^{2}$, \\ SORIANO, C.T.G. ${ }^{2}$, and PEREIRA, F.J. ${ }^{2}$
}

\begin{abstract}
The objective of this work was to evaluate the effects of the population density of Typha angustifolia plants in the anatomical and physiological characteristics. Plants were collected from populations of high density (over 50\% of colonization capacity) and low density (less than $50 \%$ of colonization capacity) and cultivated under controlled greenhouse conditions. Plants from both populations were grown in plastic trays containing $4 \mathrm{~L}$ of nutritive solution for 60 days. At the end of this period, the relative growth rate, leaf area ratio, net assimilatory rate, root/shoot ratio, leaf anatomy, root anatomy, and catalase and ascorbate peroxidase activities were evaluated. Plants from high density populations showed increased growth rate and root/shoot ratio. Low density populations showed higher values of stomatal index and density in leaves, as well as increased palisade parenchyma thickness. Root epidermis and exodermis thickness as well as the aerenchyma proportion of high density populations were reduced, these plants also showed increased vascular cylinder proportion. Only catalase activity was modified between the high and low density populations, showing increased values in low density populations. Therefore, different Typha angustifolia plants show differences in its anatomy and physiology related to its origins on high and low density conditions. High density population plants shows increased growth capacity related to lower apoplastic barriers in root and this may be related to increased nutrient uptake capacity.
\end{abstract}

Keywords: macrophytes, Typha angustifolia, morphological plasticity, plant growth, ecological plant anatomy.

RESUMO - O objetivo do trabalho foi avaliar os efeitos da origem em diferentes densidades populacionais de Typha angustifolia nas características anatômicas e fisiológicas. As plantas foram coletadas de populações muito (acima de 50\% da capacidade de colonização) e pouco adensadas (abaixo de 50\% da capacidade de colonização), sendo cultivadas sob condições controladas em casa de vegetação. As plantas de ambas as populações foram cultivadas em bandejas de plástico contendo $4 \mathrm{~L}$ de solução nutritiva por 60 dias. Ao final desse periodo, foram avaliadas a taxa de crescimento relativo, razão de área foliar, taxa assimilatória liquida, razão raiz/parte aérea, anatomia foliar e radicular, atividade da catalase e peroxidase do ascorbato. As plantas das populações muito adensadas mostraram maiores taxas de crescimento e razão raiz/parte aérea. Populações pouco adensadas apresentaram maiores valores para o indice e densidade estomáticos foliares, bem como maior espessura do parênquima paliçádico. A espessura da epiderme e exoderme nas raízes, bem como a proporção de aerênquima das populações muito adensadas foram menores, sendo que essas plantas também apresentaram maiores valores para a proporção de cilindro vascular. Somente a atividade da catalase foi diferente entre as populações, apresentando maiores valores para as populações pouco adensadas. Portanto, plantas de Typha angustifolia apresentam diferenças em sua anatomia e fisiologia relacionadas a sua origem em condições de alto ou baixo adensamento populacional. As populações muito adensadas apresentam maior capacidade de crescimento, possivelmente relacionada a reduções nas barreiras apoplásticas podendo estar associadas à maior capacidade da absorção de nutrientes.

Palavras-chave: macrófitas, Typha angustifolia, plasticidade morfológica, crescimento vegetal, anatomia vegetal ecológica.

Recebido para publicação em 16.1.2014 e aprovado em 3.12.2014.

2 Universidade Federal de Lavras, Lavras, Minas Gerais, Brasil, <felipecorrea@dbi.ufla.br>; ${ }^{3}$ Instituto Federal de Educação, Ciência e Tecnologia do Sul de Minas Gerais, Poços de Caldas, Minas Gerais, Brasil; ${ }^{4}$ Universidade Federal de Alfenas, Alfenas, Minas Gerais, Brasil. 


\section{INTRODUCTION}

Macrophytes returned from land to further occupation of lotic and lentic water ecosystems (Cook, 1996). These plants are primary producers on their environment playing a role on the nutrient cycling, organic matter production, eutrophication, and providing shelter and food to animals (Cervi et al., 2009). Macrophytes may also contribute for removal of the pollutants in these environments (Pereira et al., 2011). However, besides of its high environmental relevance, too little is known about its biology, and most of the papers published are related to plant systematics and flower surveys (Pardial et al., 2008).

To cope the new water environments, macrophytes developed many structural and physiological modifications. Some common adaptations in macrophytes includes: aerenchyma development (Castro et al., 2009; Yang et al., 2012), increased sclerenchymatous tissue development (Manus et al., 2002), alternative uptake mechanisms to water $\mathrm{CO}_{2}$ and $\mathrm{O}_{2}$ (Pierini \& Thomaz, 2004), and increased root porosity (Insausti et al., 2001).

Some macrophyte populations may exhibit higher productivity and growth, colonizing large areas. This uncontrolled growth may damage the biodiversity and anthropic activities conduced in these environments (Thomaz, 2002). According to Pereira et al. (2011), plant adaptations to its environment may be related to modifications in anatomy and physiology. These modifications may be related to plant genetic characteristics (Pereira et al., 2008; Souza et al., 2009; Doheny-Adams et al., 2012) or the environmental conditions (Wang et al., 2007; Xiao et al., 2009).

One of the most distributed macrophyte species over the world is Typha angustifolia (Typhaceae). This is an emergent macrophyte commonly called cattail which leaves are amphistomatic with sclerenchymatous fibers forming groups between the palisade and spongy parenchyma (Henry, 2003). Cattail species may cause many problems colonizing non-native environments, for example, Li et al. (2009) described the problem involving $T$. domingensis colonization reducing Cladium jamaicense populations in the Everglades. However, despite of some spots show high colonization of $T$. domingensis, occupying more than $50 \%$ of the area, in some spots plants do not colonize even $50 \%$ of its area. This must be related to nutrient concentration (Davis, 1991) but these differences may be also related to plant genetic encoding different anatomical structure and physiology characteristics. Works within anatomical and physiological modifications of different Typha species as related to excessive growth and colonization are very rare. These studies may be important to macrophyte and environmental management.

Therefore, the objective of this work was to evaluate the anatomical and physiological modifications between two Typha angustifolia populations from different natural population densities.

\section{MATERIAL AND METHODS}

Plants of $T$. angustifolia were colected at brazilian southeast region in Alfenas, Minas Gerais State, 21 252443 S, 45 562493 W, from natural water bodies. Plants were collected from high densities populations (over $50 \%$ of the area colonized by $T$. angustifolia) and low densities populations $(50 \%$ or less of the area colonized by $T$. angustifolia). About 15 plants from each population were washed with running water and grown in a greenhouse in nutrient solution (Hoagland \& Arnon, 1950) at $40 \%$ ionic strength for 60 days to obtain clonal generations acclimatized to the greenhouse.

Clone plants were standardized by size and number of leaves and polypropylene vases containing $4 \mathrm{~L}$ of nutrient solution (Hoagland $\&$ Arnon, 1950) at $40 \%$ ionic strength were used to grow the plants under the two treatment conditions: higher density populations and lower density populations. Thus, the experiment was carried out in these conditions by 60 days in completely randomized design with two treatments and 14 replications for each evaluation.

Growth evaluation was performed measuring the leaves, roots and rhizome dry mass in analytical balance at the end of the 
experiment. Dry mass was obtained by drying the plant parts in oven at $45^{\circ} \mathrm{C}$ until constant mass. Leaf area was also measured at the end of the experiment photographing the leaves and measuring its area in the software UTHSCSA-Imagetool (The University of Texas Health Science Center, San Antonio, Texas, USA). The physiological growth indexes were calculate as described by Hunt et al. (2002) and were obtained the relative growth rate (RGR), leaf area ratio (LAR), and the net assimilation rate (NAR) was obtained by multiplying (RGR*LAR). The root/shoot ratio was obtained by dividing dry mass of both parts.

For anatomical analyses 14 roots and fully developed leaves were collected and fixed in a solution of formaldehyde, acetic acid, and 70\% ethanol (F.A.A. 70) for 72 hours and then stored in $70 \%$ ethanol until further analysis (Johansen, 1997). Paradermal leaf sections were obtained at middle region using steel blades on abaxial and adaxial sides and sections were cleared with $50 \%$ sodium hypochlorite, rinsed in distilled water twice for 10 minutes, stained with $1 \%$ safranin solution, and mounted on slides with coverslips with 50\% glycerol (Kraus \& Arduin, 1940). Cross-sections were obtained at the leaf middle region and root differentiation zone using LPC type hand microtome. Sections were cleared with $50 \%$ sodium hypochlorite, rinsed in distilled water twice for 10 minutes, stained with safrablau solution (1\% safranin and $0.1 \%$ astra blue at $7: 3$ ratio), and mounted on slides with coverslips with $50 \%$ glycerol. The slides were photographed under a Zeiss MicroImaging GmbH Scope.A1 (Carl Zeiss MicroImaging GmbH, Göttingen, Germany) coupled to a Canon A630 digital camera.

The UTHSCSA-Imagetool software was used for image analysis and the following parameters were measured: (NC) - number of epidermal cells; (SPD) - stomatal polar diameter; (SED) - stomatal equatorial diameter; (SD) - stomatal density; (SI) stomatal index; (ETab) - epidermis thickness from abaxial leaf side; (ETad) - epidermis thickness from abaxial leaf side; (PPab) palisade parenchyma thickness from leaf abaxial side; (PPad) - palisade parenchyma thickness from leaf adaxial side; (SAab) sclerenchyma area from leaf abaxial side;
(SAad) - sclerenchyma area from leaf adaxial side; (AP) - proportion of aerenchymal gaps on spongy parenchyma; (DXab) - mean diameter of metaxylem vessels of vascular bundles from abaxial leaf side; (DXad) - mean diameter of metaxylem vessels of vascular bundles from adaxial leaf side; (PAab) - phloem area on vascular bundles from abaxial leaf side; (PAad) - phloem area on vascular bundles from adaxial leaf side; (VBDab) - mean distance between vascular bundles from abaxial leaf side; (VBDad) - mean distance between vascular bundles from adaxial leaf side; (RET) - root epidermis thickness; (REX) - root exodermis thickness; (RCT) - root cortex thickness; (RED) - root endodermis thickness; (XDR) mean diameter of metaxylem vessels in roots; (PT) - phloem thickness in roots; (APR) aerenchymal gaps proportion in root cortex; (VCP) - vascular cylinder proportion in roots (area/area). Five images and three fields to each image were evaluated for each slide, obtaining 420 data for each anatomical characteristic.

At the end of the experiment, 14 samples of leaves and roots were collected in the morning for biochemical analysis and then were frozen in liquid nitrogen and preserved in a freezer at $-80{ }^{\circ} \mathrm{C}$ until further analysis. Enzymes were extracted from $0.5 \mathrm{~g}$ of roots or leaves to which were added $2.0 \mathrm{~mL}$ of extraction buffer consisting of $1.924 \mu \mathrm{L}$ of $0.1 \mathrm{M}$ potassium phosphate buffer at $\mathrm{pH} 7,20 \mu \mathrm{L}$ of $0.1 \mathrm{M}$ EDTA [ethylenediaminetetraacetic acid], $8 \mu \mathrm{L}$ of $0.5 \mathrm{M}$ DTT [dithiothreitol], $16 \mu \mathrm{L}$ of 0.1 M PMSF [phenylmethanesulfonyl fluoride], and $40 \mathrm{mg}$ of PVPP [polyvinylpolypyrrolidone], as adapted from the method described by Bor et al. (2003). After homogenization, the enzyme extract was centrifuged at $14,000 \mathrm{~g}$ for 20 minutes at $4{ }^{\circ} \mathrm{C}$. The supernatant was then collected and used to determine the activity of the following enzymes: ascorbate peroxidase (APX) and catalase (CAT).

Ascorbate peroxidase (APX) activity was evaluated by adding $160 \mu \mathrm{L}$ of $0.1 \mathrm{M}$ potassium phosphate buffer $\mathrm{pH} 7,100 \mu \mathrm{L}$ of $0.005 \mathrm{M}$ ascorbic acid, $100 \mu \mathrm{L}$ of $0.005 \mathrm{M} \mathrm{H}_{2} \mathrm{O}_{2}$, and $605 \mu \mathrm{L}$ of distilled water to $35 \mu \mathrm{L}$ of the enzyme extract, as adapted from the method described by Nakano \& Assada (1981). Enzymatic activity was determined by monitoring decreasing 
absorbance in spectrophotometer (Dynamica GmbH, Halo SB-10, Zurich, Switzerland) at $290 \mathrm{~nm}$ for 2 minutes and calculated based on the extinction factor of $2.8 \mathrm{~m} \mathrm{M}^{-1} \mathrm{~cm}^{-1}$. To evaluate catalase (CAT) activity, we added $35 \mu \mathrm{L}$ of enzyme extract to $160 \mu \mathrm{L}$ of $0.1 \mathrm{M}$ potassium phosphate buffer at $\mathrm{pH} 7$, and then added $125 \mu \mathrm{L}$ of $0.01 \mathrm{M} \mathrm{H}_{2} \mathrm{O}_{2}$ dissolved in buffer and $680 \mu \mathrm{L}$ of distilled water, as adapted from the method described by Madhusudhan et al. (2003). Enzyme activity was determined by monitoring decreasing absorbance at $240 \mathrm{~nm}$ for 1 minute and calculated based on the extinction factor of $36 \mathrm{mM}^{-1} \mathrm{~cm}^{-1}$.

The data were subjected to one-way ANOVA and $F$-test at $p<0.05$ using Sisvar statistical software (Ferreira, 2003).

\section{RESULTS AND DISCUSSION}

Concerning on the physiological growth indexes, only the RGR and root/shoot ratio were changed by population densities. Plants from high population densities sites exhibited higher values for the RGR (18.07\%) and root/ shoot ratio $(29.71 \%)$ compared to the lower population densities (Figure 1A and 1D). No differences were obtained for the LAR and NAR (Figure 1B and 1C).

The relative growth rate and large amounts of biomass allocated to rhizomes may be related to large expansion of Phragmites communis populations (Liu et al., 2012). According to Inoue \& Tsuchiya (2009), T. angustifolia has similar vegetative reproduction system to the Phragmites communis species. Therefore, the higher relative growth rate of higher density populations of $T$. angustifolia may be related to its colonization capacity. This may indicate that genetical variations among $T$. angustifolia plants can be a key factor to determinate its colonization capacity and not only the environmental euthrophication.

Another growth index related to the higher colonization capacity of $T$. angustifolia plants may be the root/shoot ratio. According to Gruffman et al. (2012) and Laclau (2003), this characteristic may be related to higher investment on root system and directly related to nutrient uptake. Likewise, higher density populations may stand a higher capacity for nutrient uptake and growth.
In paradermal sections, stomata of T. angustifolia are tetracytic and distributed in both abaxial and adaxial sides of the leaves. The anticlinal walls of most epidermal cells have few sinuosites. There are parallel strips of pale epidermal cells located above the vascular bundles visible at paradermal sections (Figure 2). Stomatal quantitative characteristics were changed by population densities. Plants from high populations densities showed 3.05\% increased stomatal equatorial diameter in leaf abaxial side. Stomatal density in abaxial side was $2.82 \%$ higher in low density populations. Similar results were observed on adaxial side showing $5.09 \%$ increased values (Table 1). Stomatal index was $2.22 \%$ higher in lower density populations as well as the number of epidermal cells was $3.58 \%$ higher in this population in adaxial side (Table 1).

Stomata are specialized epidermal cells for $\mathrm{CO}_{2}$ uptake, consequently they release $\mathrm{O}_{2}$ and water. These structures play an important role on photosynthesis (Castro et al., 2009). Stomatal structure and physiology are modified by genetical and environmental modifications (Doheny-Adams et al., 2012; Ribeiro et al., 2012). As an example, plants may develop higher stomatal density and smaller stomata in order to reduce water loss and maintain the photosynthesis (Xu \& Zhou, 2008; Castro et al., 2009). Likewise, lower stomatal density and index as well as larger stomata in the higher density populations may be related to shading effects from many plants in this higher density situation. Elisson (1987) reported this shading effect on macrophyte species under higher density populations.

Leaf cross-sections showed one-seriated epidermis in both adaxial and abaxial sides followed by three layered palisade parenchyma. Collateral vascular bundles are arranged in parallel series in both abaxial and adaxial sides of the leaves. Vascular bundle sheath showed extensions of sclerenchyma fibers which connects the vascular bundles to epidermis. Spongy parenchyma is located between the two sides (abaxial and adaxial) of palisade parenchyma forming trabeculae delimitating large aerenchymal chambers (Figure 3).

Adaxial side epidermis thickness increased $4.25 \%$ in high density populations. 

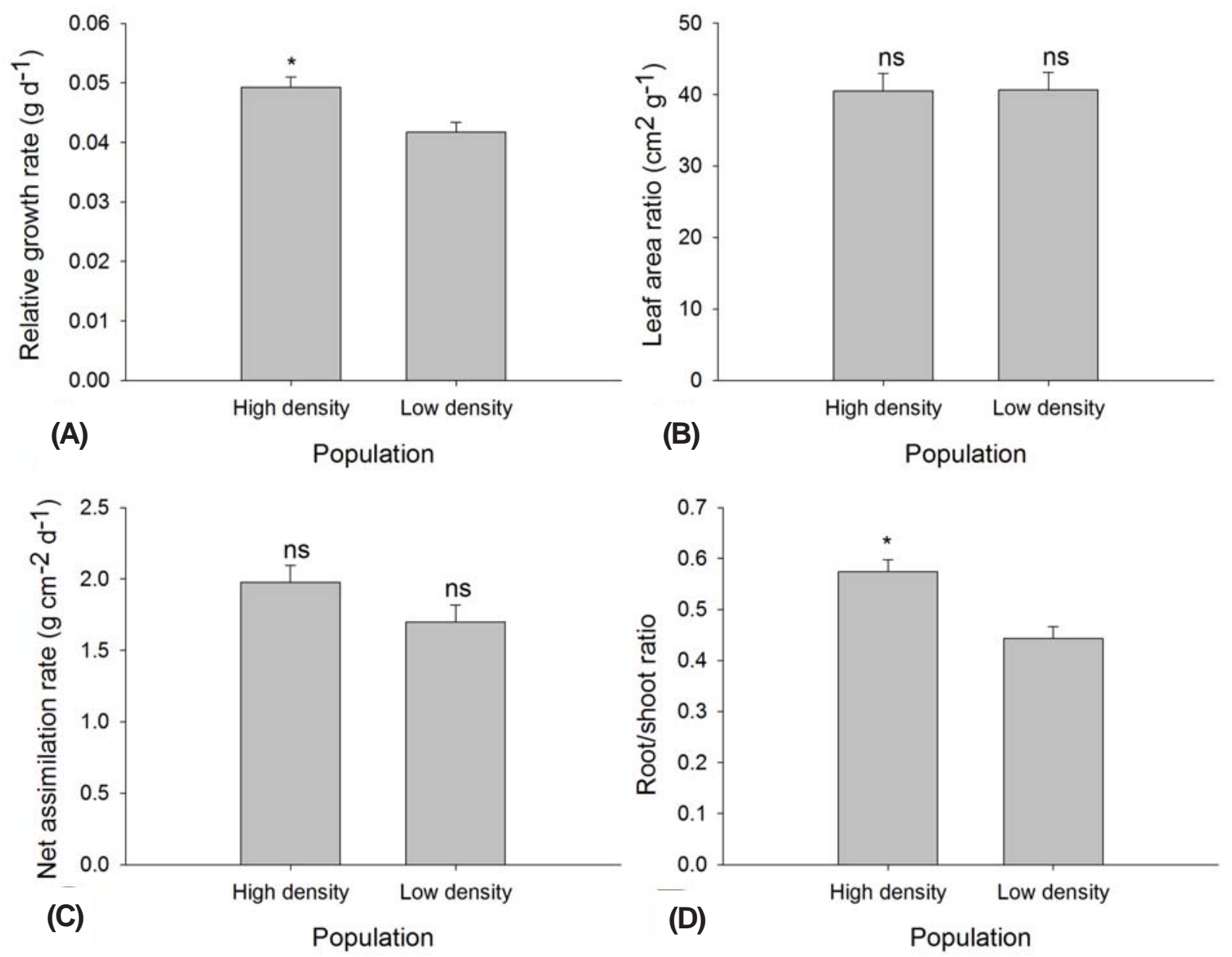

(A) relative growth rate; (B) Leaf area ratio; (C) Net assimilation rate; (D) Root/shoot ratio. * significant for F-test at $5 \%$. ${ }^{\text {ns }}$ not significant.

Figure 1 - Physiological growth indexes of Typha angustifolia from high and low population densities cultivated under nutritive solution.

Therefore, the palisade parenchyma thickness showed values $5.77 \%$ and $7.08 \%$ higher in abaxial and adaxial sides respectively in low density populations (Table 2). The proportion of aerenchyma gaps and sclerenchyma area in both surfaces do not showed significative differences between high and low density populations (Table 2). The distance between vascular bundles of adaxial side was $4.13 \%$ higher in plants from high density populations, however, at the abaxial side, low density populations showed $12.26 \%$ higher values to this characteristic (Table 2). Phloem area was $5.9 \%$ higher in abaxial side of the leaves in high density populations, and, at adaxial side, this characteristic was $7.41 \%$ higher in low density populations (Table 2). Concerning of metaxylem vessels diameter, $6.46 \%$ increased values were observed on the abaxial leaf side of low density populations and $7.72 \%$ increased values from high density populations on the adaxial leaf side (Table 2).

Palisade parenchyma thickness may be modified by environmental conditions. Catoni et al. (2012) reported lower palisade parenchyma thickness under lower temperatures and higher water availability in Cistus species. Palisade parenchyma is also directly related to photosynthesis (Souza et al., 2010) and shade leaves show a decrease of palisade parenchyma thickness in many plant species (Eschrich et al., 1989; Terashima et al., 2006). Therefore, as observed on the 

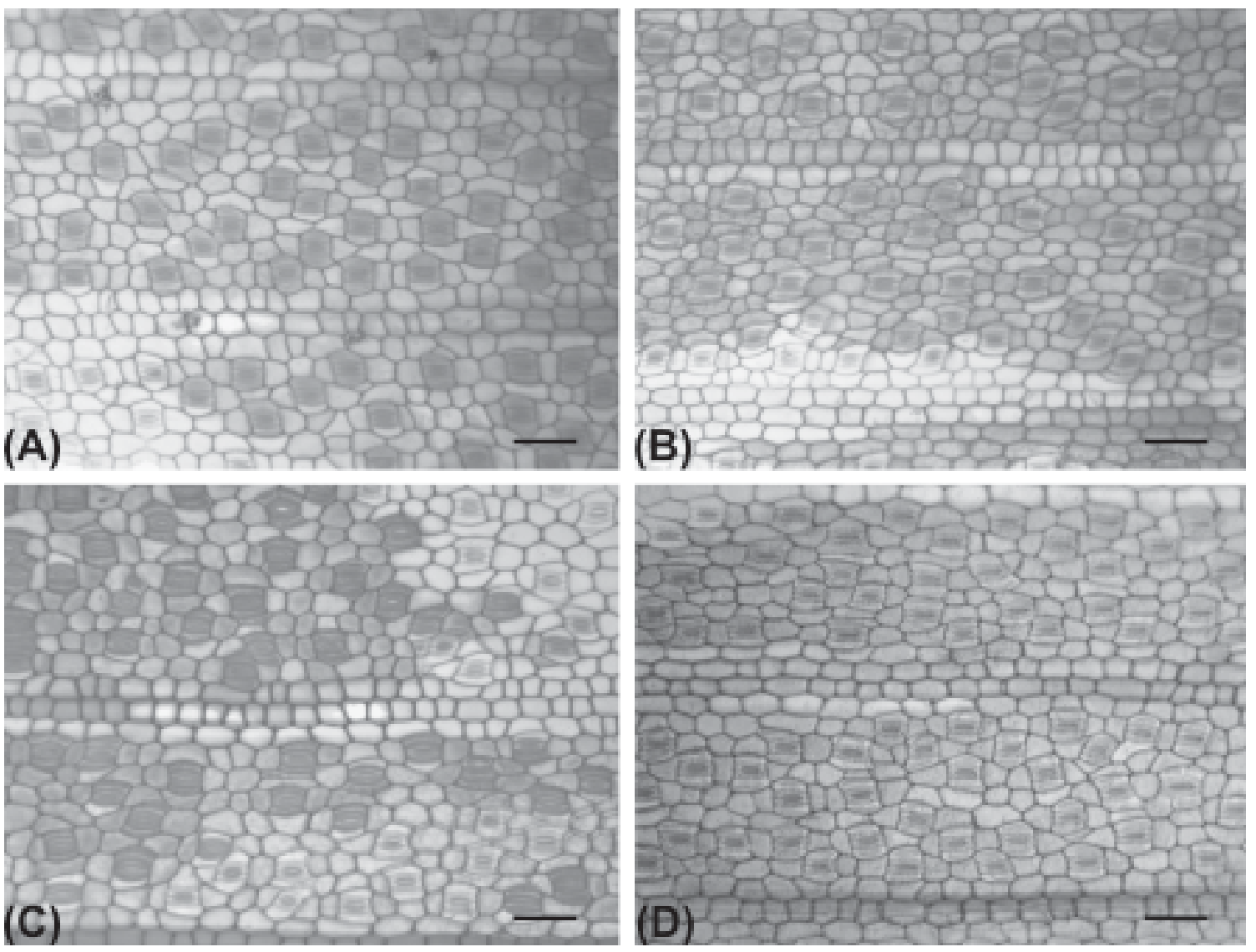

( $\mathrm{A}$ and $\mathrm{B}$ ) adaxial side; (C and D) abaxial side; (A and C) high density populations; (B and D) low density populations. Bars $=50 \mu \mathrm{m}$.

Figure 2 - Paradermal sections of Typha angustifolia leaves from different natural population densities cultivated under nutritive solution.

Table 1 - Stomatal characteristics of Typha angustifolia from different population densities cultivated under nutrient solution

\begin{tabular}{|c|c|c|c|c|c|}
\hline \multicolumn{6}{|c|}{ Leaf adaxial side } \\
\hline Population density & $\mathrm{NC}$ & $\operatorname{SPD}(\mu \mathrm{m})$ & $\operatorname{SED}(\mu \mathrm{m})$ & $\mathrm{SD}$ & SI $(\%)$ \\
\hline High density & 568.61 & $23.72^{\mathrm{ns}}$ & $13.12^{\mathrm{ns}}$ & 389.32 & 11.98 \\
\hline Low density & $588.97^{*}$ & $23.42^{\text {ns }}$ & $13.14^{\mathrm{ns}}$ & 409.13* & $12.24 *$ \\
\hline \multicolumn{6}{|c|}{ Leaf abaxial side } \\
\hline Population density & $\mathrm{NC}$ & $\operatorname{SPD}(\mu \mathrm{m})$ & $\operatorname{SED}(\mu \mathrm{m})$ & SD & SI (\%) \\
\hline High density & $628.62^{\mathrm{ns}}$ & $23.80^{\text {ns }}$ & $12.38^{*}$ & 416.60 & $11.96^{\mathrm{ns}}$ \\
\hline Low density & $637.29^{\text {ns }}$ & $24.15^{\text {ns }}$ & 12.01 & $428.38^{*}$ & $11.86^{\mathrm{ns}}$ \\
\hline
\end{tabular}

(NC) number of epidermal cells; (SPD) stomatal polar diameter; (SED) stomatal equatorial diameter; (SD) stomatal density; (SI) stomatal index. ${ }^{*}$ significant for F-test at $5 \%$. ${ }^{\text {ns }}$ not significant.

stomatal characteristics, higher density populations of $T$. angustifolia developed leaves which shows reduced palisade parenchyma as a consequence of shading effects from higher number of plants in these populations.
According to Castro et al. (2009), leaf epidermis is related to plant defenses against high radiation rates, pathogens and mechanical injuries. Therefore, higher epidermal thickness may provide a higher 
defense against pathogens (Hansen et al., 2007; Mussury et al., 2012) and, its increased values on high plant population densities may be related to more efficient defense mechanisms. The increased

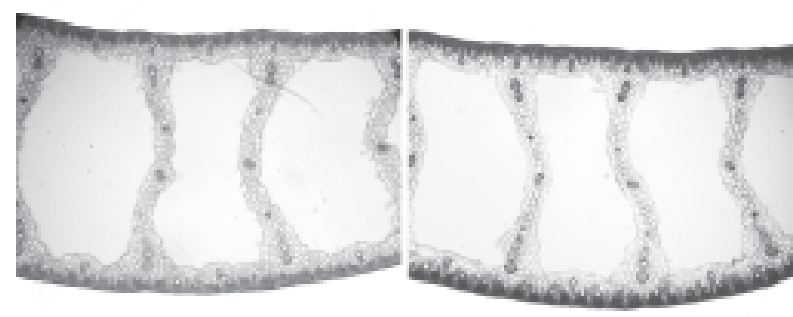

(A)

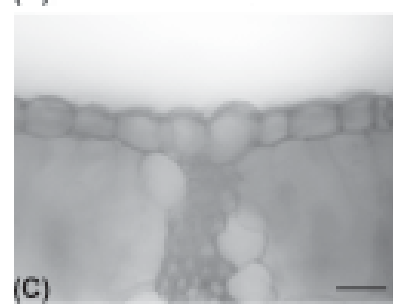

(B)
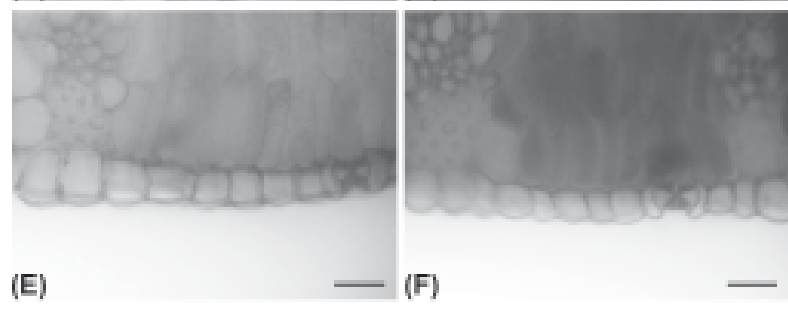

(E)
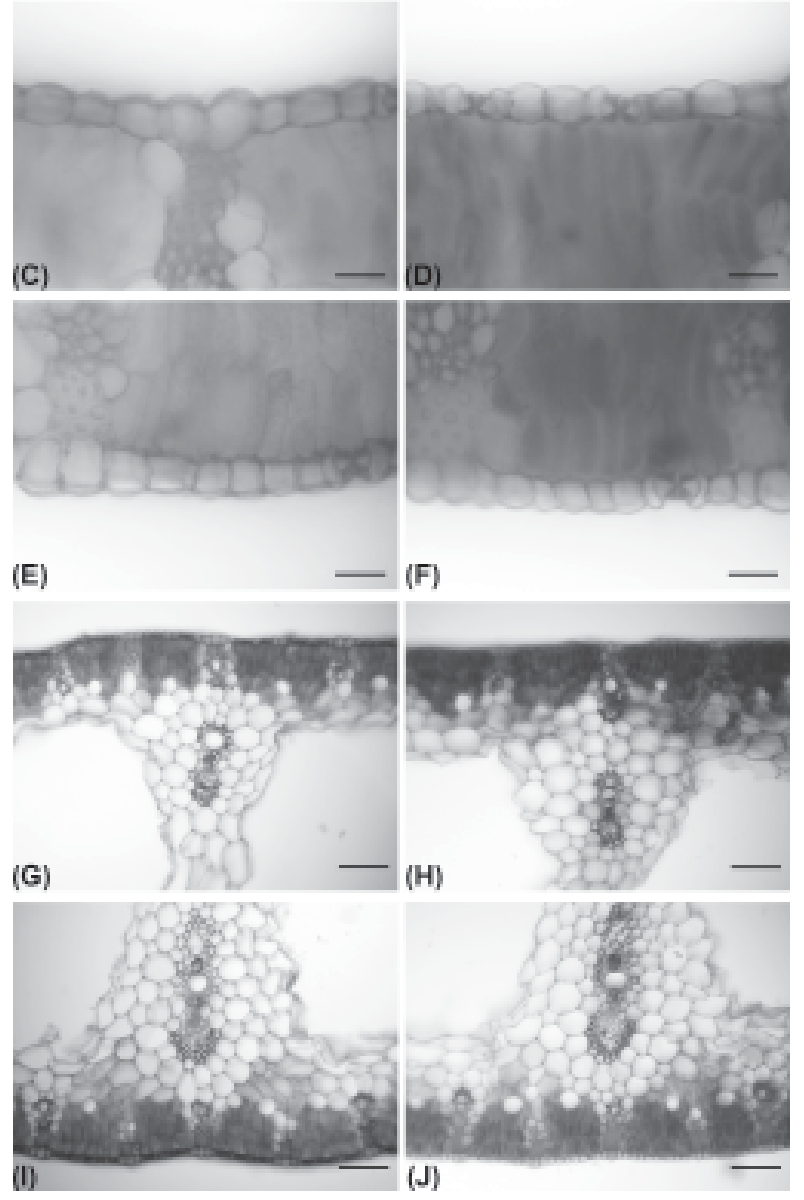

(A and B) leaf blade, bars $=1000 \mu \mathrm{m} ;(\mathrm{C}, \mathrm{D}, \mathrm{E}$, and F) epidermis and palisade parenchyma details, bars $=20 \mu \mathrm{m} ;(\mathrm{G}, \mathrm{H}, \mathrm{I}$, and $\mathrm{J})$ epidermis and palisade parenchyma details, bars $=100 \mu \mathrm{m}$; (C, D, G, and H) adaxial side; (E, F, I, and J) abaxial side; (A, C, E, G, and I) high density population; (B, D, F, H, and J) low density populations.

Figure 3 - Cross sections of Typha angustifolia leaves from different natural population densities cultivated under nutritive solution. epidermal thickness may be a response of $T$. angustifolia plants against the high population density.

Concerning on the vascular system, larger xylem vessel diameter and phloem thickness are related to higher transport capacity for water, nutrients and photoassymilates (Pereira et al., 2008; Schuldt et al., 2013). However, longer distances between vascular bundles may reflect on lower transport capacity (Marques et al., 2012). Different T. angustifolia populations may develop different adaptations on the adaxial and abaxial sides of its leaves. This may equal both populations concerning on vascular system.

Macrophyte adaptations to water environments including aerenchyma production as well as large sclerenchyma tissues development in plant leaves are basic requirements to its survival and colonization capacity. According to Armstrong et al. (2000) aerenchyma is responsible for gas storage providing adequate gas supply for plant respiratory and photosynthetic metabolism. Sclerenchyma on the other hand, are related to plant support above water providing more efficient radiation and atmospheric gas uptake (Manus et al., 2002). Both T. angustifolia populations showed similar sclerenchyma development independent of the population density showing little influence of this characteristic on leaf adaptations under different population densities in this species.

Typha angustifolia shows one-seriated root epidermis which has few trichomes. Root cortex is separated in external cortex (which contains parenchymatous cells and few intercellular spaces), median cortex which contains several aerenchyma gaps, and internally, T. angustifolia develops an internal cortex containing parenchyma cells. The parenchyma cells on root cortex showed no highspecialization, these cells shows decreased size near the vascular cylinder. Root endodermis is one-seriated followed by one or two parenchymatous pericycle cells. Vascular cylinder is tetrarch at the sampled region and has large metaxylem elements and phloem located between the external protoxylem poles (Figure 4). 
Table 2 - Leaf anatomical modifications of Typha angustifolia from different population densities cultivated under nutrient solution

\begin{tabular}{|c|c|c|c|c|c|c|c|c|}
\hline \multicolumn{9}{|c|}{ Leaf blade tissues characteristics } \\
\hline Population density & $\begin{array}{l}\text { ETab } \\
(\mu \mathrm{m})\end{array}$ & $\begin{array}{l}\text { ETad } \\
(\mu \mathrm{m})\end{array}$ & $\begin{array}{l}\text { PPab } \\
(\mu \mathrm{m})\end{array}$ & & & $\begin{array}{l}\text { SAab } \\
\left(\mu \mathrm{m}^{2}\right)\end{array}$ & $\begin{array}{l}\text { SAad } \\
\left(\mu \mathrm{m}^{2}\right)\end{array}$ & $\begin{array}{l}\text { AP } \\
(\%)\end{array}$ \\
\hline High density & $13.73^{\mathrm{ns}}$ & $15.04 *$ & 95.57 & & & $1023.09^{\text {ns }}$ & $990.06^{\mathrm{ns}}$ & $66.0^{\mathrm{ns}}$ \\
\hline Low density & $13.69^{\mathrm{ns}}$ & 14.43 & $101.08 *$ & & $34 *$ & $1024.58^{\text {ns }}$ & $1015.17^{\text {ns }}$ & $66.0^{\mathrm{ns}}$ \\
\hline \multicolumn{9}{|c|}{ Vascular tissues characteristics } \\
\hline Population density & $\begin{array}{c}\text { DXab } \\
(\mu \mathrm{m})\end{array}$ & $\begin{array}{c}\text { DXad } \\
(\mu \mathrm{m})\end{array}$ & \multicolumn{2}{|c|}{$\begin{array}{l}\text { PAab } \\
\left(\mu \mathrm{m}^{2}\right)\end{array}$} & \multicolumn{2}{|c|}{$\begin{array}{l}\text { PAad } \\
\left(\mu \mathrm{m}^{2}\right)\end{array}$} & $\begin{array}{c}\text { VBDab } \\
(\mu \mathrm{m})\end{array}$ & $\begin{array}{c}\text { VBDad } \\
(\mu \mathrm{m})\end{array}$ \\
\hline High density & 44.12 & $39.46^{*}$ & \multicolumn{2}{|c|}{$4957.90 *$} & \multicolumn{2}{|c|}{2809.78} & $119.47 *$ & 107.35 \\
\hline Low density & $46.97 *$ & 36.63 & \multicolumn{2}{|c|}{4681.62} & \multicolumn{2}{|c|}{$3017.88^{*}$} & 114.74 & $120.51^{*}$ \\
\hline
\end{tabular}

(ETab) epidermal thickness from abaxial leaf side; (ETad) epidermal thickness from abaxial leaf side; (PPab) palisade parenchyma thickness from leaf abaxial side; (PPad) palisade parenchyma thickness from leaf adaxial side; (SAab) sclerenchymal area from leaf abaxial side; (SAad) sclerenchymal area from leaf adaxial side; (AP) proportion of aerenchymal gaps on spongy parenchyma; (DXab) mean diameter of metaxylem vessels of vascular bundles from abaxial leaf side; (DXad) mean diameter of metaxylem vessels of vascular bundles from adaxial leaf side; (PAab) phloem area on vascular bundles from abaxial leaf side; (PAad) phloem area on vascular bundles from adaxial leaf side; (VBDab) mean distance between vascular bundles from abaxial leaf side; (VBDad) mean distance between vascular bundles from adaxial leaf side. $*$ significant for F-test at $5 \% .{ }^{\text {ns }}$ not significant.

Low density populations plants showed $4.47 \%$ higher epidermis and $7.72 \%$ higher exodermis thickness in roots compared to high density populations. These plants showed $24.12 \%$ larger aerenchyma gap proportion compared to higher density populations. In despite, high density population plants showed $7.4 \%$ higher proportion of the vascular cylinder in roots (Table 3 ). There were not significant differences to the metaxylem vessels diameter, cortex thickness, endodermis thickness, and phloem thickness between low and high density $T$. angustifolia populations (Table 3).

Epidermis and exodermis are both related to the control of apoplastic water flux, as well as many dissolved compounds on this solution. Therefore, these tissues are referred as apoplastic barriers (Hammed et al., 2009; Meyer et al., 2011). Likewise, lower epidermal and exodermal thickness observed on higher density populations of $T$. angustifolia may provide higher efficiency on water and nutrients uptake, leading to higher growth potential.

Aerenchymal tissues are essential for maintenance of aerobic metabolism in aquatic plants. In despite, the aerenchyma formation may decrease hydraulic conductance (Pereira et al., 2008; Yang et al., 2012). Accoding to Yang et al. (2012) larger proportion of aerenchyma in roots may reduce the water and nutrient uptake in rice plants. Therefore, higher density populations of $T$. angustifolia may produce lower aerenchyma proportion on roots in order to optimize water and nutrient uptake under this high competitive situation.

Larger proportion of vascular cylinder may provide higher hydraulic conductance on roots. Souza et al. (2009) reported higher values of this characteristic on maize genotypes more adapted to waterlogging soils. High density populations of $T$. angustifolia may develop larger vascular cylinders in roots as a response for competitive stress, leading for more adapted roots to water and nutrient uptake.

Catalase activity was $157.59 \%$ higher in plants from low density populations. However, catalase activity was not modified by different plant organs (Figure 5). Leaves and roots do not exhibited different activity for the ascorbate peroxidase between different population densities (Figure 6).

Several contamination conditions may lead to modifications on antioxidant system enzymes. According to Pereira et al. (2011) Eichhornia crassipes plants may increase catalase and ascorbate peroxidase activities under arsenic stress. The antioxidant system enzymes of $T$. angustifolia plants may also be modified by heavy metals (Bah et al., 2011; 

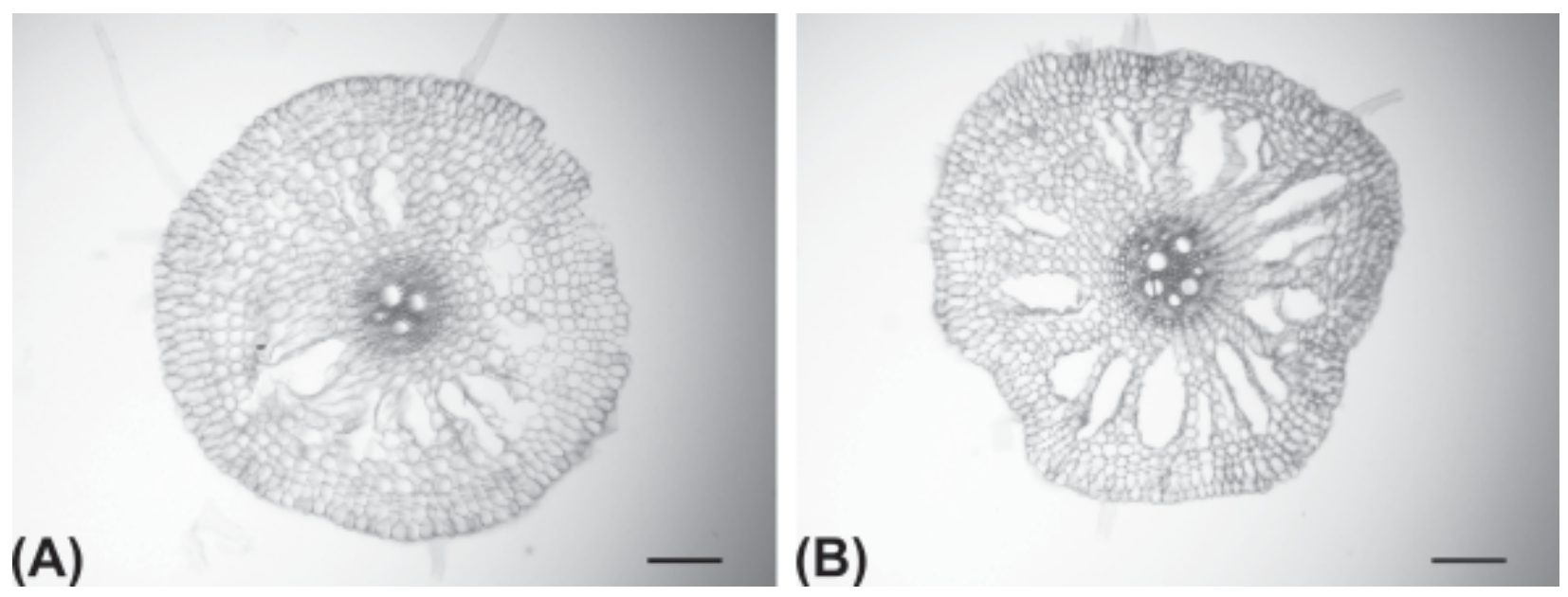

(A) high density population; (B) low density population. Bars $=100 \mu \mathrm{m}$.

Figure 4 - Cross sections of Typha angustifolia roots from different natural population densities cultivated under nutrient solution.

Table 3 - Root anatomical modifications of Typha angustifolia from different population densities cultivated under nutrient solution

\begin{tabular}{|l|l|l|l|l|l|l|l|l|}
\hline \multicolumn{1}{|c|}{ Population density } & $\begin{array}{l}\text { RET } \\
(\mu \mathrm{m})\end{array}$ & $\begin{array}{c}\text { REX } \\
(\mu \mathrm{m})\end{array}$ & $\begin{array}{c}\text { RCT } \\
(\mu \mathrm{m})\end{array}$ & $\begin{array}{c}\text { RED } \\
(\mu \mathrm{m})\end{array}$ & $\begin{array}{c}\text { XDR } \\
(\mu \mathrm{m})\end{array}$ & $\begin{array}{c}\text { PT } \\
(\mu \mathrm{m})\end{array}$ & $\begin{array}{c}\text { APR } \\
(\%)\end{array}$ & $\begin{array}{c}\text { VCP } \\
(\%)\end{array}$ \\
\hline High density & 21.41 & 19.76 & $291.51^{\mathrm{ns}}$ & $7.38^{\mathrm{ns}}$ & $24.35^{\mathrm{ns}}$ & $12.57^{\text {ns }}$ & 15.1 & $32.0^{*}$ \\
\hline Low density & $22.37^{*}$ & $21.28^{*}$ & $284.15^{\text {ns }}$ & $11.54^{\text {ns }}$ & $24.11^{\text {ns }}$ & $12.36^{\text {ns }}$ & $18.8^{*}$ & 30.0 \\
\hline
\end{tabular}

(RET) root epidermis thickness; (REX) root exodermis thickness; (RCT) root cortex thickness; (RED) root endodermis thickness; (XDR) mean diameter of metaxylem vessels in roots; (PT) phloem thickness in roots; (APR) aerenchymal gaps proportion in root cortex; (VCP) vascular cylinder proportion in roots (area/area). ${ }^{*}$ significant for F-test at $5 \% .{ }^{\text {ns }}$ not significant.
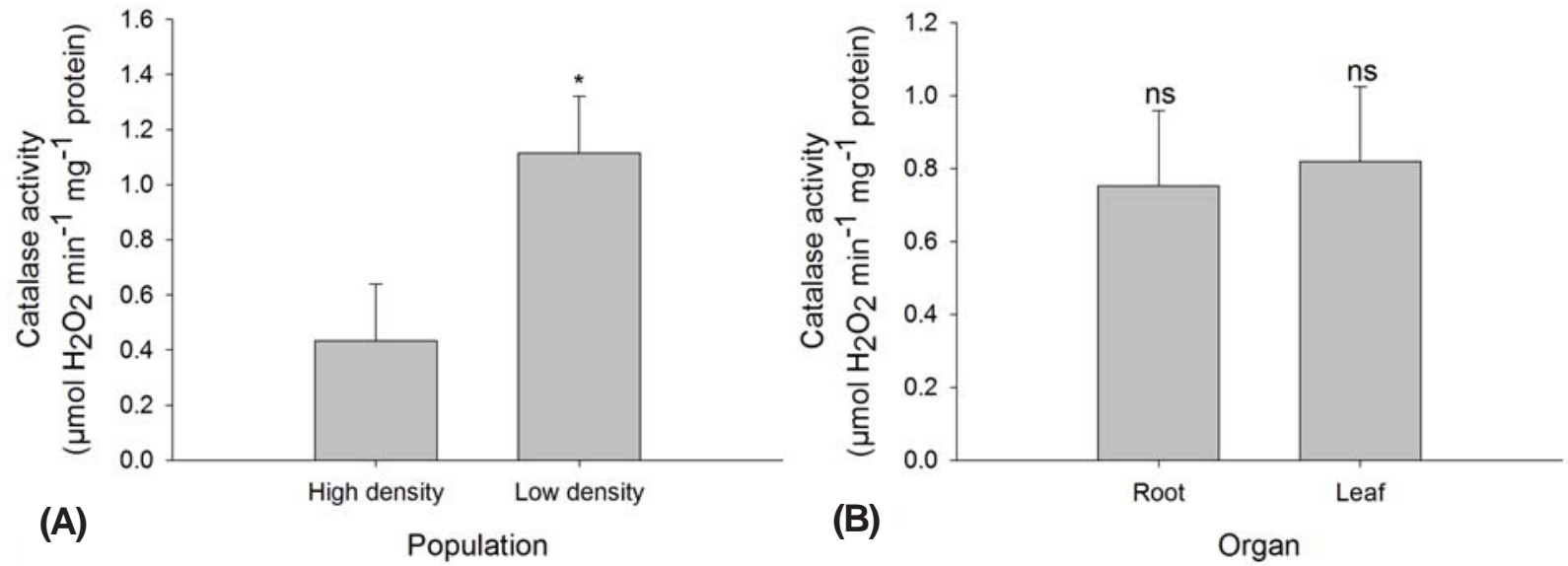

(A) comparison between high and low population densities; (B) comparison between roots and leaves independent of population densities.

* significant for F-test at 5\%. ${ }^{\text {ns }}$ not significant.

Figure 5 - Catalase (CAT) activity of Typha angustifolia cultivated under nutrient solution. 

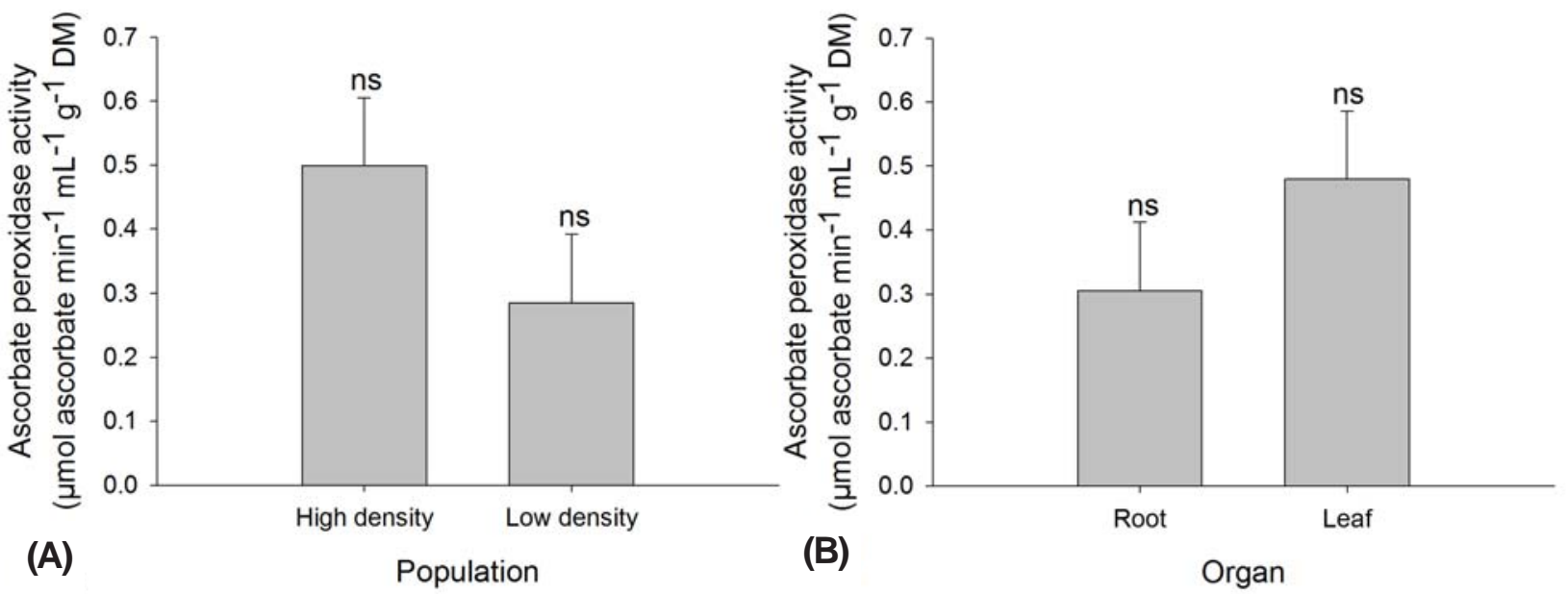

(A) comparison between high and low population densities; (B) comparison between roots and leaves independent of population densities. * significant for F-test at $5 \%$. ${ }^{\text {ns }}$ not significant.

Figure 6 - Ascorbate peroxidase (APX) activity of Typha angustifolia cultivated under nutrient solution.

Xu et al., 2011). Lower density populations of T. angustifolia may exhibit higher catalase activity in leaves as a response to higher radiation intensity, promoted by the lower number of plants.

In conclusion, $T$. angustifolia from different population densities shows modification on growth capacity, anatomy and on antioxidant system enzymes. Most of the differences between high and low density populations of $T$. angustifolia are related to growth parameters and root anatomy. Higher density populations of $T$. angustifolia shows higher capacity of growth and this may be related to higher water and nutrient uptake related to anatomical modifications in roots.

\section{ACKNOWLEDGEMENTS}

The authors thank CNPq (Conselho Nacional de Desenvolvimento Científico e Tecnológico [National Counsel of Technological and Scientific Development]), CAPES-PRODOC (Coordenação de Aperfeiçoamento de Pessoal de Nivel Superior [Coordination for the Improvement of Higher Education Personnel]), and FAPEMIG (Fundação de Amparo à Pesquisa do estado de Minas Gerais [Minas Gerais State Research Foundation]) for funding and research grants awarded to complete the present study.

\section{LITERATURE CITED}

ARMSTRONG, W. et al. Oxygen distribution in wetland plant roots and permeability barriers to gas-exchange with the rhizosphere: a microelectrode and modelling study with Phragmites australis. Ann. Bot., v. 86, n. 3, p. 687-703, 2000.

BAH, A. M. et al. Effects of Cadmium, Chromium and Lead on Growth, Metal Uptake and Antioxidative Capacity in Typha angustifolia. Biol. Trace Elem. Res., v. 142, n. 1, p. 77-92, 2011.

BOR, M. et al. The effect of salt stress on lipid peroxidation and antioxidants in leaves of sugar beet Beta vulgaris $\mathrm{L}$. and wild beet Beta maritima L. Plant Sci., v. 164, n. 1, p. 77-84, 2003.

CASTRO, E. M. et al. Histologia vegetal: estrutura e função de órgãos vegetativos. Lavras: Universidade Federal de Lavras, 2009. 234 p.

CATONI, R. et al. Physiological, morphological and anatomical trait variations between winter and Summer leaves of Cistus species. Flora, v. 207, n. 6, p. 442-449, 2012.

CERVI, A. C. et al. Macrófitas aquáticas do município de General Carneiro, Paraná, Brasil. Biota Neotrop., v. 9, n. 3, p. 215-222, 2009.

COOK, C. D. K. Aquatic plant book. Amsterdam: SPB Academic Publishing, 1996. 228 p. 
DAVIS, S. M. Growth, decomposition and nutrient retention of Cladium jamaicense Crantz and Typha domingensis Pers. in the Florida Everglades. Aquatic Bot., v. 40, n. 3, p. 203-224, 1991.

DOHENY-ADAMS, T. et al. Genetic manipulation of stomatal density influences stomatal size, plant growth and tolerance to restricted water supply across a growth carbon dioxide gradient. Phil. Trans. R. Soc. B, v. 367, n. 1586, p. $547-555,2012$.

ELISSON, A. M. Effects of competition, disturbance, and herbivory on Salicornia europaea. Ecology, v. 68, n. 3, p. 576-586, 1987.

ESCHRICH, W. et al. The induction of sun and shade leaves of the European beech (Fagus sylvatica L.): anatomical studies. Trees, v. 3, n. 1, p. 1-10, 1989.

FERREIRA, D. F. Programa SISVAR: Sistema de Análise de Variância. Versão 4.6 (Build 6.0). Lavras: DEX/UFLA, 2003.

GRUFFMAN, L. et al. Cultivation of Norway spruce and Scots pine on organic nitrogen improves seeling morphology and field performance. For. Ecol. Manag., v. 276, p. 118-124, 2012.

HAMMED, M. et al. Anatomical adaptations to salinity in cogon grass [Imperata cylindrica (L.) Raeuschel] from the Salt Range, Pakistan. Plant Soil, v. 322, n. 1-2, p. 229-238, 2009.

HANSEN, P. V. et al. Anatomy and cytology of Taphrina entomospora during infection of Nothofagus. Mycol. Res., v. 111, n. 5 , p. 592-598, 2007.

HENRY, R. Ecótonos nas interfaces dos ecossistemas aquáticos. São Carlos: Rima, 2003. 349 p.

HOAGLAND, D. R.; ARNON, D. I. The water-culture method for growing plants without soil. California Agric. Exper. Station. Cir., v. 347, n. 1, p. 1-39, 1950.

HUNT, R. et al. A modern tool for classical plant growth analysis. Ann. Bot., v. 90, n. 4, p. 485-488, 2002.

INOUE, T.; TSUCHIYA, T. Depth distribution of three Typha species, Typha orientalis Presl, Typha angustifolia L. and Typha latifolia L., in an artificial pond. Plant Spec. Biol., v. 24, n. 1, p. 47-52, 2009.

INSAUSTI, P. et al. Flooding induces a suite of adaptive plastic responses in the grass Paspalum dilatatum. New Phytol., v. 152, n. 2, p. 291-299, 2001.

JOHANSEN, D. A. Plant microtechnique. 2.ed. New York: Mc-Graw-Hill, 1940. 523 p.
KRAUS, J. E.; ARDUIN, M. Manual básico em métodos em morfologia vegetal. Seropédica: EDUR, 1997. 221 p.

LACLAU, P. Root biomass and carbon storage of ponderosa pine in a northwest Patagonia plantation. For. Ecol. Manag., v. 173, n. 1-3, p. 353-360, 2003.

LI, S. et al. Does sulphate enrichment promote the expansion of Typha domingensis (cattail) in the Florida Everglades.

Freshwater Biol., v. 54, n. 9, p. 1909-1923, 2009.

LIU, B. et al. The colonization of active sand dunes by rhizomatous plants through vegetative propagation and its role in vegetation restoration. Ecol. Eng., v. 44, p. 344-347, 2012.

MADHUSUDHAN, R. et al. Characterization of an ascorbate peroxidase in plastids of tobacco BY-2 cells. Physiol. Plant., v. 117, n. 4, p. 550-557, 2003.

MANUS, H. A. et al. Epifluorescent and histochemical aspects of shoot anatomy of Typha latifolia L., Typha angustifolia L., and Typha glauca Godr. Ann. Bot., v. 90, n. 1, p. 1-5, 2002.

MARQUES, R. P. et al. Características da anatomia foliar de espécies de braquiária e sua relação com a sensibilidade a herbicidas. Planta Daninha, v. 30, n. 4, p. 809-816, 2012.

MEYER, C. J. et al. Permeability of Iris germanica's multiseriate exodermis to water, $\mathrm{NaCl}$, and ethanol. J. Exper. Bot., v. 62, n. 6, p. 1911-1926, 2011.

MUSSURY, R. M. et al. Anatomia foliar de soja infectada por Phakospora pachyrhizi H. Sydow \& Sydow e tratadas com extratos vegetais. R. Bras. Plant Medic., v. 14, n. 1, p. 18-25, 2012.

NAKANO, Y.; ASSADA, K. Hidrogen peroxide is scavenged by ascorbate specific peroxidase in spinach chloroplast. Plant Cell Physiol., v. 22, n. 5, p. 867-880, 1981.

PARDIAL, A. A. et al. The study of aquatic macrophytes in Neotropics: a scientometrical view of the main trends and gaps. Braz. J. Biol., v. 68, n. 4, p. 1051-1059, 2008.

PEREIRA, F. J. et al. Evolução da anatomia radicular do milho 'Saracura' em ciclos de seleção sucessivos. Pesq. Agropec. Bras., v. 43, n. 12, p. 1649-1656, 2008.

PEREIRA, F. J. et al. Mecanismos anatômicos e fisiológicos de plantas de aguapé para a tolerância à contaminação por arsênio. Planta Daninha, v. 29, n. 2, p. 259-267, 2011.

PIERINI, S. A.; THOMAZ, S. M. Adaptações de plantas submersas à absorção de carbono inorgânico. Acta Bot. Bras., v. 18, n. 3, p. 629-641, 2004.

RIBEIRO, M. N. O. et al. Anatomia foliar de mandioca em função do potencial para tolerância à diferentes condições ambientais. R. Ci. Agron., v. 43, n. 2, p. 354-361, 2012. 
SCHULDT, B. et al. Changes in wood density, wood anatomy and hydraulic properties of the xylem along the root-to-shoot flow path in tropical rainforest tress. Tree Physiol., v. 33, n. 2, p. 161-174, 2013.

SOUZA, T. C. et al. Morpho-anatomical characterization of root in recurrent selection cycles for flood tolerance of maize (Zea mays L.). Plant Soil Environ., v. 55, n. 11, p. 504-510, 2009.

SOUZA, T. C. et al. Leaf plasticity in successive selection cycles of 'Saracura' maize in response to periodic soil flooding. Pesq. Agropec. Bras., v. 45, n. 1, p. 16-24, 2010.

TERASHIMA, I. et al. Irradiance and phenotype: comparative eco-development of sun and shade leaves in relation to photosynthetic $\mathrm{CO}_{2}$ diffusion. J. Exper. Bot. v. 57, n. 2 , p. $343-354,2006$.

THOMAZ, S. M. Fatores ecológicos associados à colonização e ao desenvolvimento de macrófitas aquáticas e desafios de manejo. Planta Daninha, v. 20, n. 1, p. 21-33, 2002.
WANG, W. et al. Leaf anatomical responses to periodical waterlogging in simulated semidiurnal tides in mangrove Bruguiera gymnorrhiza seedlings. Aquat. Bot., v. 86, n. 1, p. 223-228, 2007.

XIAO, Y. et al. Leaf and stem anatomical responses to periodical waterlogging in simulated tidal floods in mangrove Avicennia marina seedlings. Aquat. Bot., v. 91, n. 3, p. 231-237, 2009.

$\mathrm{XU}, \mathrm{W}$. et al. Mechanisms of cadmium detoxification in cattail (Typha angustifolia L.) Aquat. Bot., v. 94, n. 1, p. 37-43, 2011.

XU, Z.; ZHOU, G. Responses of leaf stomatal density to water status and its relationship with photosynthesis in a grass. J. Exper. Bot., v. 59, n. 12, p. 3317-3325, 2008 .

YANG, X. et al. Drought-induced root aerenchyma formation restricts water updake in Rice seedlings supplied with nitrate. Plant Cell Physiol., v. 53, n. 3, p. 495-504, 2012. 